\title{
The employability skills among students of Public Higher Education Institution in Malaysia
}

\author{
Mohamad Zuber Abd Majid ${ }^{1}$, Muhammad Hussin ${ }^{1}$, Muhammad Helmi Norman ${ }^{1}$, Saraswathy \\ Kasavan $^{2}$ \\ ${ }^{1}$ Faculty of Education, \\ Universiti Kebangsaan Malaysia \\ ${ }^{2}$ Institute for the Environment and Development, \\ Universiti Kebangsaan Malaysia
}

Correspondence: Mohamad Zuber Abd Majid (email: zuber.abdul@ymail.com)

Received: 16 August 2019; Accepted: 05 November 2019; Published: 27 February 2020

\begin{abstract}
Entering the fourth industrial revolution, many crucial changes took place in the developing economies, especially in the context of the job market. Higher education institution plays an important role in generating labours resources outputs in order to fulfil the demand of the potentials labour in the job market. Hence, strategy in the success of the workforce at the institution of education needs to improve the employability skills. The purpose of this study was to examine the graduates' employability skills among students of Public Higher Education Institution (IPTA) in Malaysia based on demography (gender, location and parental education). In addition, this study also attempts to examine the influencing factors such as endurance force, time management, research experience and activities involvement at university against employability skills. The sample of the study involved 554 undergraduate students in IPTA. The findings show that result on location demographics found significant differences; location was found to affect the level of employability of respondents. The finding also revealed that the factors of endurance force, time management, research experience and activities involvement in university are influencing variances and total predictor factors $(75.6 \%)$ for employability skills among students IPTA. The contribution of this study can provide a comprehensive comparison of the employability skills based on location demographic and endurance force aspect among the undergraduate in IPTA.
\end{abstract}

Keywords: employability skills, endurance force, gender, location, parental education, public higher education institution

\section{Introduction}

In the recent decade, higher educational institutions play an important role to develop the potentials human resources for fulfil various employment demands in the labour market (Yanti et al., 2015; Yusof \& Jamaluddin, 2015; Amiruddin et al., 2016; Siti Mistima et al., 2018). As today's business environment is infinite and borderless, employers are looking for 
well-rounded employees who have the employability skills (such as communication; teamwork; problem solving; initiative and enterprise; planning and organising; selfmanagement; long-life learning and technology) in hiring (Muhammad Hazrul, 2012; Chitra, 2013). Those employability skills are considered a valuable asset to employers (Mohamad Sattar et al., 2010; Mohamad Sattar et al., 2012; Makhbul, Yussof \& Awang, 2015) and also help to gain the competitive advantage as well as leads survival the organization products or services in the global market (Anuar et al., 2016; Hanapi et al., 2016; Rahmat et al., 2016). Similarly, through the study of Yelasmanchili (2018), the aspects of employability skills such as leadership skills will influence the culture of critical thinking and build more competitive teamwork within an organization. As such, students need to be exposed to the real working environment, thus, higher education institutions shall create access to established resources to enhance their personal experience.

Employability skills are also known as job readiness skills which needed by students to prepare themselves to become a competent and competitive worker after they have completed their studies. According to Hillage and Pollard (1998), the term of employability skills is a capability to move sufficiency within the labour market to realize a potential through sustainable employment. In a similar perspective, according to Naddhirah (2014) and Mohammad Sattar et al. (2014), employability skills are an individual capability for his or her own to practice and determine the skills of employability to sustain and cater in a job environment. In general, employability skills required not only to gain employment, but it's also a progress of employee to carry out their role to the best of their ability towards achieve the potential strategic organization or business.

Gaining employment is considered a crucial factor in measuring the success of a higher educational institution, particularly graduates who have a degree level education. Based on research conducted by Nooriah and Zakiah (2017), large numbers of first degree students in public university are still jobless due to a lack of experience, poor communication skills and also pursued studies irrelevant to the job market. The Department of Statistics, Malaysia (2016) has issued a statement illustrating the unemployment rate among first degree graduates increased from 20.83 per cent in 2013 to 24.9 per cent by 2015. Meanwhile, PEMANDU (2012) points out that, only 75 per cent is a level of employability of higher education institution to reach in order to fulfil graduate employability was produced. It clearly highlights that higher education in public university has yet to reach the average level of employability skills, but below the prescribed level (Graduate Detection Review, 2016). In the other hand, Malaysia Job Vacancies (2018), reported that trend of job vacancies in Malaysia is increasing from year to year, but these job vacancies are fulfilled by only some part of workers. This obviously shows that the lack of job opportunities is not key reasons for increasing the unemployment rate in Malaysia. Instead, it happens because low employability skills among the graduates, particularly first degree students in Public Higher Education Institution (IPTA) unable to fulfil the existing those job vacancies. Therefore, the study of demographic factors coincides with the aspiration and factor that affect student employability skills, so that the prospects for graduates to work can be improved.

Next, understanding and exploration in the gender demographic it is a sign to explore because the term in the enrolment ratio continue their study between male and female is an unbalanced at IPTA's. Thus, in terms of production from IPTA according the Graduate Detected Review report series between 2011 until 2017 reveal that graduate who get the job after six month graduation period in term in gender show that male have higher percentage getting the job compare than female only lower percentage getting a job. The difference percentage getting the job among the gender, mean that exists the ability from male and female in the context of employability skills will be highlighted. Employability and location also in highlighted in this study to explore the existing graduate who come from urban and 
rural area in term gaining the employability skills. In fact, from the previous study report that graduate who come from rural family have a pure skill of employability compared for those graduates who come from rural family (Blunt \& Richards, 1998; Syed Kamarudin, 2016; Syed Kamarudin et al., 2017). This study also highlighted the parental education background as the variable gaining the employability skills among the undergraduate in IPTA's. The parental education background it is a significant variable to explored, because of term a revolution in the education in that era, who have a knowledgeable parent are assumed as influence their children (Eccles, 2005). The previous study also found that very limited exploration about parental education background, especially in context employability is needed to highlight. The reviewing from previous study also highlighted several factors that influence employability based on the student participation and perform in the campus survival during their study period. The factor such as endurance force, time management, research experience and activity are involved at university is needed to explore to encourage an employability to resolve.

This study was conducted to examine the differences in employability skills based on demographic factors for gender, location and parental education background among Malaysia public university students. In addition, this study also attempts to examine the influencing factors such as endurance force, time management, and research experience and activities involvement in university against employability skills among the first degree students at public universities. The findings of this study can be utilized as a major reference point by institutions of higher education that will help in order to prepare themselves towards the real face of employability. Throughout the program of study, the higher institution learning needs to be insert the job skills which will ultimately produce graduates with full knowledge and soft skills. The impact of employability skills is guarantee factor of success in the current face of the job and market career requirement. The contribution of this study can provide a comprehensive comparison of the employability skills based on demographic aspect among the undergraduate in IPTA. This can evidently conduct the employability strategy by notifying where the emphasis should be and which recommendations could have a greater impact on improving employability skills.

\section{Hypotheses}

Based on objective above, the hypothesis is proposed as follows:

Ho1 There is no significant differences between employability skills based on gender.

Ho2 There is no significant differences between employability skills based on location.

Ho3 There is no significant differences between employability skills based on parental education (father and mother education background).

Ho4 There is no significant influence between endurance force, time management, research experience and activities involvement at university against employability.

\section{Research Design}

This study is in line with the quantitative study approach which cross sectional survey is used as a research design. A total of 850,000 graduate students in all public universities in Malaysia are the study population. By referring to Cohen et al. (2001), the minimum sample recommendation is 384 samples. In this study, researchers succeeded in determining 554 students (311 male and 243 female) as the total number of samples. The data were gathered using structure and self-administered questionnaires. The reliability values for items are: 
employability construct at $\alpha=0.93$; endurance force at $\alpha=0.92$; time management at $\alpha=$ 0.90 ; research experience at $\alpha=0.84$; and activities involvement in university at $\alpha=0.94$. The higher the Cronbach Alpha value, the higher the reliability of the items in explaining their construct (Geore \& Mallery, 2011). Statistical analysis of inferential studies is adapted, where $t$ test is used to examine the difference in employability for demographic aspects. While, multiple regression test (step-wise method) was used to examine the factor influencing the employability skills. Researchers have complied with the requirement to carry out parametric statistical analysis based on the suggestion made by Chua (2014).

\section{Results and discussion}

\section{Differences in employability skills based on demographic factors}

Based on Table 1, the variance of employability skills based on gender is $t=1.288$ and Sig. $=$ 0.198 ( $\mathrm{P}>0.05)$. The finding shows that there is no difference in employability skills based on gender. These results are consistent with those of Sok, Blomme, and Tromp (2013); Marrison (2014); Jackson and Wilton (2017) who gender to have no impact influence the employability skills. However, this finding in terms of the mean score of the test proves that female slightly higher $($ mean $=3.82$, standard deviation $=0.37$ ) employability skills compared to male (mean $=3.77$, standard deviation $=0.47$ ). This result may be explained by the fact that female students are more informed in terms of their certain employability skills that matter in the industry. However, this finding is not in line with the findings of research conducted by Rivera (2011); Tomlinsom (2012); and Tholen (2014), which found that male have more self-perceived employability compare than female. The result also not in line with the research conducted by Malaysia Ministry of Higher Education (2017) on Graduate Detected Review report series between 2011 until 2017 in the contexts of gender reveal that male have more employability compare than female. The phenomena reveal that a male has more value in employability skills compared than female in the market labour.

Table 1. The differences employability skills score base on gander

\begin{tabular}{lllllll} 
Gander & $\mathbf{N}$ & Mean & $\begin{array}{l}\text { Standard } \\
\text { Deviation }\end{array}$ & $\mathbf{t}$ & Df & Sig. \\
\hline Male & 311 & 3.77 & 0.47 & 1.288 & 552 & 0.198 \\
Female & 243 & 3.82 & 0.37 & & & \\
\hline
\end{tabular}

Based on Table 2, the variance of employability skills based on location is $t=3.622$ and Sig. $=0.001(\mathrm{P}<0.05)$. The finding shows that there are differences in location, demographic factors, influencing the graduates' employability of higher education institutions in Malaysia. One of interesting finding is students from urban areas have higher employability skills $(\mathrm{M}=3.85, \mathrm{SD}=0.38)$ compared to rural area students $(\mathrm{M}=3.72, \mathrm{SD}=$ 0.47). A possible reason for this is that students from the urban area have experience of enjoying different resources, have different governance structures, and provide different learning environments from city comparable to student from rural areas. These results reflect those of Blunt and Richards (1998), Syed Kamarudin (2016) and Syed Kamarudin et al. (2017) who also found that residential locations would affect individuals in term of value and desirability, which is influencing student's employability. The adequate exposure due to the accessibility of certain facilities and extracurricular activities in city schools were influenced urban area students to become more up to date to current changes towards improving employability skills. 
Table 2. The Differences employability skills score base on location

\begin{tabular}{lllllll}
\hline Location & $\mathbf{N}$ & Mean & $\begin{array}{l}\text { Standard } \\
\text { Deviation }\end{array}$ & t & Df & Sig. \\
\hline Urban & 293 & 3.85 & 0.38 & 3.622 & 540 & 0.001 \\
Rural & 249 & 3.72 & 0.47 & & & \\
\hline
\end{tabular}

Based on Table 3, the score differences employability skills base on demographic factor in father education background is $\mathrm{t}=2.560$ and Sig. $=0.11(\mathrm{P}>0.05)$ and mother education background is $\mathrm{t}=1.161$ and Sig. $=0.246(\mathrm{P}>0.05)$. The findings indicate that there is no significant difference in employability skills based on parent education background. However, this finding in terms of the mean score of the $t$ test proves that the influence by parent education level to employability skills among the undergraduate. In the other word, the parent with degree level of education more influence of value employability skills among their children's or otherwise. This finding is in line with those of previous study Syed Kamarudin (2016). Usually, educated parents will teach human capital skills to their children through communication, related to their own experiences and knowledge.

Table 3. The differences employability skills score base on parental education

\begin{tabular}{|c|c|c|c|c|c|c|}
\hline $\begin{array}{l}\text { Parental } \\
\text { Education }\end{array}$ & $\mathbf{N}$ & Mean & $\begin{array}{l}\text { Standard } \\
\text { Deviation }\end{array}$ & $\mathbf{t}$ & Df & Sig. \\
\hline \multicolumn{7}{|c|}{ Father Education Background } \\
\hline School & 310 & 3.75 & 0.39 & 2.560 & 540 & 0.11 \\
\hline Degree & 232 & 3.84 & 0.46 & & & \\
\hline \multicolumn{7}{|c|}{ Mother Education Background } \\
\hline School & 394 & 3.78 & 0.39 & 1.161 & 540 & 0.246 \\
\hline Degree & 148 & 3.83 & 0.49 & & & \\
\hline
\end{tabular}

\section{Influencing variances and predictor factors of employability skills}

The value of significant level of regression for $t$ test is lower than 0.05 , indicating that result will be influenced. Besides that, the significance level for variance analysis also is lower than 0.05 , indicating that result will be a predictor. Based on Table 4 , the variance of employability and predictor factor is significant, which is influence for employability among students IPTA. The result is $\mathrm{F}=401.673$, Sig. $=0.001(\mathrm{P}<0.05)$.

Table 4. The varian analysis

\begin{tabular}{llllll}
\hline Sources & Total Squared & Df & Mean Squared & F & Sig. \\
\hline Regression & 67.961 & 4 & 16.990 & 401.673 & 0.001 \\
Residual & 21.657 & 512 & 0.042 & & \\
Total & 89.681 & 516 & & & \\
\hline
\end{tabular}

Figure 1 shows that, the contribution factor for employability between predictor factors. Total percentage of predictor for employability is 75.6 percent, which is divided by four factors of predictor. The highest predictor influencing the employability is an endurance force factor of 68.5 percent, followed by time management at 6.2 percent, research experience at 0.7 percent and the lowest predictor is activity involved in university around 0.2 percent. 


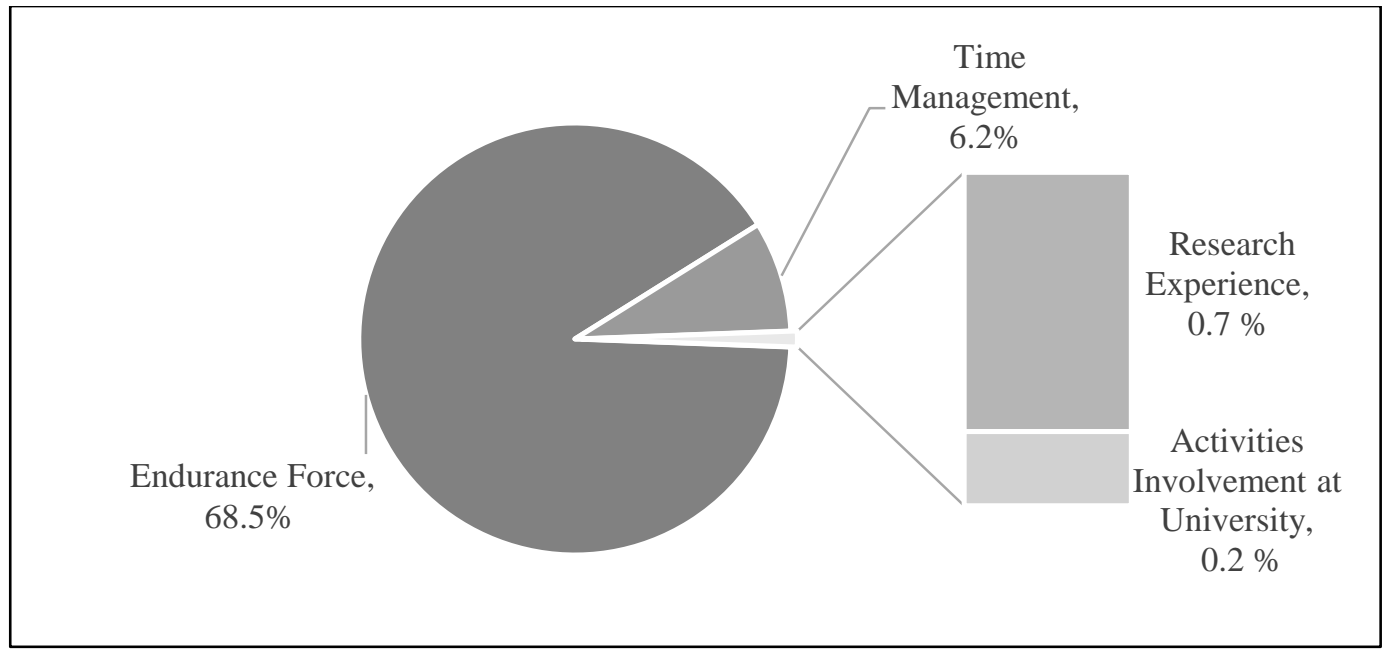

Figure 1. The percentage predictor against employability

Table 5 shows that, the finding for $\mathrm{t}$ test in regression analysis. The highest influencing predictor is an endurance force at $\beta=0.392, \mathrm{t}=13.862$, sig. $=0.001(\mathrm{P}<0.05)$, followed by time management at $\beta=0.392, \mathrm{t}=11.106$, Sig. $=0.001(\mathrm{P}<0.05)$, research experience at $\beta=$ $0.085, \mathrm{t}=3.335$, Sig. $=0.001(\mathrm{P}<0.05)$, and the lowest influencing predictor is activity involved in university which is at $\beta=0.047, \mathrm{t}=2.080, \mathrm{Sig} .=0.036(\mathrm{P}<0.05)$. The equation of multiple regressions is illustrated as follows:

$$
\begin{aligned}
& \mathrm{Y}=\mathrm{a}+\mathrm{b}_{1} x_{1}+\mathrm{b}_{2} x_{2}+\mathrm{b}_{3} x_{3}+\mathrm{b}_{4} x_{4} \\
& \mathrm{Y}=0.52+0.488 x_{1}+0.392 x_{2}+0.085 x_{3}+0.047 x_{4}
\end{aligned}
$$

Whereas:

Y - Employability

a - Constant

$X$ - Factors ( $x_{1}$ Endurance Force), ( $x_{2}$ Time Management), ( $x_{3}$ Research Experience $),\left(x_{4}\right.$ Activities Involvement at University)

\begin{tabular}{|c|c|c|c|c|c|c|}
\hline \multirow[t]{2}{*}{ Variable } & \multicolumn{2}{|c|}{$\begin{array}{l}\text { Unstandardized } \\
\text { Coefficients }\end{array}$} & \multirow{2}{*}{$\begin{array}{l}\text { Standardized } \\
\text { Coefficients } \\
\text { Beta }\end{array}$} & \multirow[t]{2}{*}{$\mathbf{T}$} & \multirow[t]{2}{*}{ Sig. } & \multirow[t]{2}{*}{$\mathbf{R}^{2}$} \\
\hline & B & $\begin{array}{l}\text { Default } \\
\text { Error }\end{array}$ & & & & \\
\hline Endurance Force & .465 & .034 & .488 & 13.862 & .001 & 0.686 \\
\hline Time Management & .335 & .030 & .392 & 11.106 & .001 & 0.749 \\
\hline $\begin{array}{l}\text { Research } \\
\text { Experience }\end{array}$ & .053 & .016 & .085 & 3.335 & .001 & 0.755 \\
\hline $\begin{array}{l}\text { Activities } \\
\text { involvement } \\
\text { university }\end{array}$ & .052 & .025 & .047 & 2.080 & .036 & 0.756 \\
\hline
\end{tabular}

Table 5. The regression analysis against employability

a. Predictors: (Constant), Endurance force

b. Predictors: (Constant), Endurance force, Time management

c. Predictors: (Constant), Endurance force, Time management, Research experience

d. Predictors: (Constant), Endurance force, Time management, Research experience, Activities involvement at university

The findings of this study are in line with the study conducted by Syed Kamaruddin (2016) that the endurance factor is a major contributor to the level of Malaysian students graduating from at the Institute of Higher Education (IPT). This finding explains the aspects of endurance such as the consistency of stress, physical endurance, adaptability, risk-taking, 
enthusiasm, high motivation, and willingness to work hard for success. Generally, the endurance aspect can be trained and acquired through life skills or trained skills such as generic skills and soft skills at educational institutions. This statement is also supported by the endurance theory, pioneered by Richardson (2002) that the internal power known as durability emphasizes the aspect of the internal power of a person, possessed by the individual in shaping the character, value and strength of the work. The endurance aspect of the job has been extra-focused by employers in an effort to hire potential employees with high motivational motivation, confidence and ability to develop their own career, thus, increase organizational productivity (Ishak et al., 2008).

The finding also suggests that time management factors are influential on the employability of first-degree graduates IPTA at 6.2 percent. The findings of this study are in line with the study conducted by Syed Kamaruddin (2016) that time management is the second greatest factor affecting the level of graduates in IPT. Time management skills are essential and are very much needed in daily life management. Term of time plays an important role in macroeconomic cycles and is associated with the business and the growth of an organization. Similarly, in the study conducted by Olowookere et al. (2015), there was a positive and significant relationship between time management training and character development which led to academic achievement among first degree graduates in Nigeria. The findings are also supported by Shazia and Muhammad Saqib (2015) for those students who have a good time management at higher education tend to be more successful. That means, students who portray a good time management will be assumed as students who possess good discipline and have better plans in everything they do.

The findings show that 0.7 percent of research experience influences employability. Similarly, for university experience factor, only 0.2 percent influences the student employability. The experiential aspect gained by students in institutions of higher education through their involvement with curriculum activities, co-curriculum, teaching staff and career information which are aspects in the development of employability skills. However, the findings of this study are not consistent with the study conducted by Nurfariha and Muhammad (2015) in which the aspect of curriculum experience does not have a significant effect on the skills of the student employability, but on the other hand student readiness is a contributor to the skills of employability. The results are also in line with research conducted by Heekyung (2017) showing that the lowest percentage is an experience factor which is, in fact, in terms of career perspective, education institution in Korea is not giving career guidance experience by not encouraging participation among students. In contrast, the study conducted by Kamsuriah et al. (2012) in unification acquired the findings showing that the aspects of curriculum experience fulfilled by students in educational institutions are aspects that influence the employability in which students will be more competitive in the job market. The learning experiences offered by the institution are cultivated by participating students indirectly through teaching and learning activities, especially in terms of employability skills.

\section{Conclusion and Recommendations}

The aim of the present research was to examine the differences between employability skills based on demographic factor such as gender, location and parental education background. From the results, a location factor is a significant factor affecting graduates' employability skills. This study also examines the predictor factor that influencing employability among undergraduate students at public universities. Hence, institutions are a key to improve employability (Mohamad Sattar et al., 2014) thus; creating the environment and nature of a modern campus atmosphere with information technology is in line with the desire to nurture 
graduates who are equipped with the latest skills. From the findings, the researchers have proposed some suggestions as a job strategy among graduates of higher education institutions in Malaysia. These suggestions can be applied or set up as a platform to develop guidelines and strategies for enhancing employability skills which in turn will develop human potential to meet the needs of the labour market.

- The students themselves must firstly be clear by the choice and the results of a discipline or career, as well as career paths. Connecting students with key industry players is one of the most appropriate actions besides ensuring that the curriculum and learning experience are appropriate.

- Higher education institutions need to make high graduate's marketability as the ultimate goal and strategy to shine in the eyes of the world. In fact, the involvement of professionals as instructors and advisor at the beginning (first semester) or throughout the years is so anticipated. In other words, students will be explicitly stated about the most relevant graduate employability skills when learning the courses.

- In order to improve the employability skills among the students, institutions of higher education must be aware of the market's needs via teaching delivery, curriculum, physical facility and technologies.

- The institutions of higher education should be providing more community-based co-curricular activities, clubs, sports, and businesses that will definitely open up the mind which will directly improve the employability skills among the students.

- The industry or employers should be increased opportunities throughout offer work experience, placements and internships among the final year student towards improving the employability skills. It's also provide an opportunity to the students be employable once have graduated from institutions of higher education.

- The government should play a significant role by contributing to the job schemes so that more job opportunities can be created.

- Small industry companies need to be given equal chances to give students an experience to improve their job skills. However, there will be financial constraints; therefore, government needs to provide additional funding to higher education institutions and small and medium industry players to offer job training and placement.

\section{References}

Amiruddin, M.H., Ngadiran, I.A., Zainudin, F.L., \& Ngadiman, N. (2016). Tahap kemahiran generik pelajar Malaysia dalam proses pengajaran dan pembelajaran: Kajian kes pelajar Institut Kemahiran Mara, Johor Baharu. Geografia: Malaysian Journal of Society and Space, 3(3), 111-121.

Anuar, A.R., Nurmahfuzah, W., Wan, J., \& Din, B.H. (2016). Cabaran meningkatkan produktiviti syarikat berskala kecil dan sederhana di Malaysia: Kajian mengenai isu kemahiran buruh. Geografia: Malaysian Journal of Society and Space, 4(4), 26-33.

Blunt, A. \& Richards, G. (1998). The work value of marginalized adult learners. Adult Basic Education, 8(3), 157-175.

Chua Y.P. (2014). Basic statistic of research (3th edition). Kuala Lumpur: McGraw-Hill Education (Malaysia) Sdn. Bhd.

Cohen, L., Manion, L. \& Morrison, K. (2001). Research methods in education (5 ${ }^{\text {th }}$ edition) London: Routledge Falmer. 
Chitra, R. (2013). Employability skills: A study on the perception of the engineering students and their prospective employers. Global Journal of Management and Business Studies, 3, 525-534.

Eccles, S.,J. (2005). Influence of parents' education on their children's educational attainments: the role of parent and child perceptions. London Review of Education, 3(3), 191-204.

George, D. \& Mallery, P. (2011). SPSS for windows step by step: A sample guide and reference, 10.0 update. Bostan: Ally \& Bacon.

Hanapi, Z., Kamis, A., Kiong, T.T., \& Hanapi, M.H. (2016). Jurang integrasi kemahiran employabiliti di Malaysia: Satu kajian empirikal graduan kejuruteraan Kolej Komuniti. Geografia: Malaysian Journal of Society and Space, 3(3), 145-153.

Heekyung, C. (2017). The role of career counselling in job and career development. Journal Social Sciences and Humanities, 25, 29-38.

Hillage, J. \& Pollard, E. (1998). Employability: Developing a framework for policy analysis. EFEE Research Briefing 85.

Ishak, Y., Rahmah, I. \& Robiah, S. (2008). Graduan dan alam pekerjaan: Kes siswazah UKM. Journal of Southeast Asia Social Sciences and Humanities, 72, 3-24.

Kamsuriah, A., Noor Faridatul, A.Z., Sufian, I. \& Masura, R. (2012). Relationship between employability and program outcomes achievement. Procedia - Social and Behavioural Sciences, 59, 254-263.

Makhbul, Z.M., Yussof, I., \& Awang, A.H. (2015). Antara realiti dan harapan - Kajian empirikal persepsi majikan terhadap prestasi graduan tempatan. Geografia: Malaysian Journal of Society and Space, 10(10), 27-36.

Malaysia Department of Statistics. (2016). Annual unemployment statistics. Retrieved from http://www.statistics.gov.my/ (5 May 2017).

Malaysia Ministry of Higher Education. (2015). Graduate Detection Review Report 2015. Putrajaya, Malaysia.

Malaysia Ministry of Higher Education. (2017). Graduate Detection Review Report 2017. Putrajaya, Malaysia.

Krejcie, R.V. \& Morgan, D.W. (1970). Determining sample size for research activities. Educational and Psychological Measurement, 30(3), 607-610.

Marrison, A.R. (2014). You have to be well spoken: Student view on employability within the graduate labour market. Journal of Education and Work, 27(2), 179-98.

Muhamad Hazrul Ismail. (2012). Kajian mengenai kebolehpasaran siswazah di Malaysia: Tinjauan dari perspektif majikan. Prosiding PERKEM, Jilid 2, 906-913.

Mohammad Sattar, R., Mohd Yusof, I., Napisah, I., Muhammad Rashid, R., \& Rose Amnah, A.R. (2010). Development of employability skills assessment tool for manufacturing industry. Journal Mechanical, 30, 48-61.

Mohamad Sattar, R., Rose Amah, A.R., Azlin Norhaini, M., \& Puvanasvaran, A.P. (2012). Employability skills assessment tool development. International Education Studies, 5(5), 43-56.

Mohamad Sattar, R., Rose Amah, A.R., \& Ahmad Rosli, M.N. (2014). Future employability skills set for manufacturing industries. International Education Studies, 7(10), 138144.

Naddhirah, M.A., Salleh, A., \& Ame Husna, K. (2014). Kebolehpasaran graduan suatu analisa literatur. Persidangan Antarabangsa Pendidikan dan Kaunseling, 273-274.

Nooriah,Y., \& Zakiah, J. (2017). Development of graduates employability: The role of university and challenges. Jurnal Personalia Pelajar, 20,15-32. 
Nurfariha, I. \& Muhammad, H. (2015). Kemahiran kebolehpasaran dalam kalangan pelajar Universiti Kebangsaan Malaysia. International Conference on Global Education III. Ekasakti Press.

Norliana, H., Chang, P.K. \& Mat Pauzi, A.R. (2016). Stops: Mengungkai isu kebolehpasaran graduan di Malaysia. Jurnal Komunikasi: Malaysian Journal of Communication, 32(2), 139-164.

Olowookere, E.I., Alao, A.A., Odukoya, J.A., Adekeye, O.A. \& Agbude, G.A. (2015). Time management practices, character development and academic performance among university undergraduates: Covenant unversity experience. Creative Education, 6, 7986.

PEMANDU. (2012). Economic Transformations Plan Annual Report 2012. Putrajaya: Prime Minister's Department.

Rahmat, N., Ayub, A.R., \& Buntat, Y. (2016). Employability skills constructs as job performance predictors for Malaysian polytechnic graduates: A qualitative study. Geografia: Malaysian Journal of Society and Space, 3(3), 154-167.

Richardson, G.E. (2002). The met theory of resiliency. Journal of Clinical Psychology, 58(3).

Rivera, L.A. (2011). Ivies, extracurriculars and exclusion: Elite employers' use of education credential. Research in Social Stratification and Mobility, 29(1), 71-90.

Shazia, N., \& Muhammad Saqib, K. (2015). The impact of time management on the students' academic achievements. Journal of Literature, Languages and Linguistics, 11, 66-71.

Siti Mistima, M., Zatul Iradah, A.K., Nurasikin, S., \& Nurul Naimy, W. (2018). Validating students employability skills using Comfirmatory Factor Analysis among engineering technology students. Journal of Advance Research and Control Systems, 10, 16071613

Sok, J., Blomme, J., \& Tromp, D. (2013). The use of the psychological contract to explain self-perceived employability. International Journal of Hospitality Management, 34, 247-84.

Syed Kamarudin, S., Muhammad, H., \& Hamidun, B. (2017). Marketability and employability among Institutions of Higher Learning (IPT) students in Malaysia. Research Journal of Applied Sciences, 12, 228-294.

Syed Kamarudin, S. (2016). The level of emploability and workability among Malaysia gradates in higher of education. Thesis of Doctarate. FPEN: National University of Malaysia.

Tholen, G. (2014). The changing nature of the graduate labour market: Media, policy and political discourse in the UK. London: Palgrave MacMillan.

Tomlinson, M. (2012). Gradated employability: A review of conceptual and empirical themes. Higher Education Policy, 25(4), 407-31.

Yanti, R., Ismarul, Y.I., \& Nur Zakiah, M.S. (2015). Discipline-based employability skills among the students in Health-Related Faculties in UKM, Kuala Lumpur Campus. Advance Science Letters, 21, 2409-2412.

Yelsmanchili, R.K. (2018). Relationship between leader behaviour and subordinate intensive to remain: Mediating role of critical thinking and empowerment. Academy of Strategic Management Journal, 17(8), 1-15.

Yusof, N., \& Jamaluddin, Z. (2015). Graduate employability and preparedness : A case study of University of Malaysia Perlis (UNIMAP), Malaysia. Geografia: Malaysian Journal of Society and Space, 11(11), 129-143. 